\title{
The Factors of Reinforcing Global Independence of the External Auditor: Case of Tunisian Enterprises
}

\author{
Wided Bouaine \\ Assistant Professor, Higher Institute of Accountancy and Corporate Management \\ University of Manouba, Campus Universitaire 2010, Manouba, Tunisia \\ Modélisation Comptable, Financière et Economique (MOCFINE) \\ Yosr Hrichi (Corresponding author) \\ Assistant Professor, Faculty of Economics and Management of Nabeul \\ University of Carthage, Campus Universitaire Mrezga 8000, Nabeul, Tunisia \\ Modélisation Comptable, Financière et Economique (MOCFINE) \\ E-mail: yosr.hrichi@fsegn.u-carthage.tn
}

Received: October 30, 2018 Accepted: December 28, 2018 Published: January 8, 2019

doi:10.5296/ijafr.v9i1.13992

URL: https://doi.org/10.5296/ijafr.v9i1.13992

\begin{abstract}
The global independence of the external auditor is decomposed into real and perceived independence. The aim of this article is to analyze the factors enhancing the global independence of the Tunisian auditor by classifying them as factors related to the auditor, the auditing firm and the audited company. In one hand, our results shows that training, sector specialization and the audit committee reinforce real and perceived auditor's independence. In fact, the auditor with a higher degree of education is enables to issue an unbiased audit report. The sector specialization guarantees the auditor's ability to be rigorous and independent during the audit assignment. The audit committee which has a legitimate and informative power limits any pressure on auditor's independence. In addition, the audit tenure has a negative effect on the perceived independence and the voluntary rotation decreases the real independence because managerial pressures can force the auditor to give a favorable opinion on the financial statements and the rotation can affects the auditor's perception of his future fees. We can therefore conclude that achieving a global independence of the auditor is a difficult task because of the ambiguity of the assessment of the real independence of the Tunisian auditor.
\end{abstract}

Keywords: Real independence, Perceived independence, Formation, Sector specialization, Reputation, Audit tenure and audit committee 


\section{Introduction}

The audit of accounts is an efficient tool of managing an enterprise which allows the reassurance of the shareholders regarding the decisions taken by the managers (Watts and Zimmerman, 1986). Indeed, companies are required to appoint an auditor responsible for certifying the financial statements in order to ensure representation of the true value of the company (Windsor and Ashkanasy, 1995).

The auditor must have a capital of competence and independence to be able to detect and refer to the anomalies discovered in the financial statements (DeAngelo, 1981). These two qualities enable external users to be reassured as far as the objectivity and integrity of the opinion of the auditor are concerned (Novie, 2013).

The independence of the auditor is decomposed into a real independence and a perceived independence. This independence is threatened by several factors such as pressure from senior management (Krishnamurthy and al 2006), acceptance of consulting assignments by the auditor, the risk of establishing a link with familiarity of the audited company, the accumulation of functions, and the weak governance (Daniels and Booker, 2011). As a remedy, the Sarbanes Oxley law (2002) was adopted to strengthen the quality of financial reporting and the real and perceived independence of the external auditor.

Independence is defined as "the ability to exercise in freedom, in reality and in appearance, authority and powers conferred by law to the statutory auditors" (Knapp, 1985). Similarly, Prat-Dit-Hauret (2003) defines the independence as «the auditor's ability to make objective judgments, which are free and clear of any kind of influences exerted by other parties."

Thus, the independence is a necessary condition that allows the auditor to perform his work with a high degree of critical thinking, which guarantees an objective assessment of the financial statements (Bamber and Iyer, 2007, Mills and al., 2011).

Knapp (1985) show that independence is composed of real or fact independence and a perceived or apparent independence. These two complementary components are necessary to ensure the relevance and quality of the audit (Richard, 2006).

The real independence is defined by The International Ethics Standards Board for Accountants (IESBA) as «as state of mind which allows the making of an opinion without being affected by influencers which compromise the professional judgment by allowing the professional to adequately perform his professional skepticism and to deal with his mission in integrity and objectivity.

So Compernolle (2008) certifies that this independence is a mental attitude, a state of mind in the sense that the auditor should be alerted against the pressures that can affect that quality. The real independence allows the auditor to achieve objectivity in formulating his judgment. So this mental quality guarantees his autonomy with regard to his client and his freedom to express a professional opinion on the financial statements. However, Richard (2003) argues that this independence is an intangible and ambiguous quality. 


\section{MInstitute Macrothink $_{\text {Int }}$}

International Journal of Accounting and Financial Reporting

ISSN 2162-3082

2019, Vol. 9, No. 1

The Perceived independence is a quality based on public perception (Bertin and Godowski (2010). Enhancement of objectivity of the auditor preserves the public's confidence and guarantees the legitimacy of its mission (Prat Dit Hauret, 2003). In this contexte, Quick and Warming-Rasmussen (2015) show a significantly positive relationship between investor confidence and auditor independence.

Real independence alone cannot maintain shareholder confidence because it is difficult to observe (Compernolle, 2008), the auditor should be and appear independent, that is to say that he must not only retain a critical capacity that allows him to perform his role with objectivity and integrity, but also, he should appear, to different parts, free from any relationship that may affect his integrity and objectivity.

To design the perceived independence, IESBA provides a clear definition of this concept. It has to do with « the need to avoid the significant facts and circumstances that a third part who is reasonably informed, would judge that the integrity, objectivity or critical spirit of a firm or of an audit team member have not been compromised.

The global independence is influenced by many factors (Mills and al., 2011) related to the auditor and the audited company (Dopuch and King, 2013; Zhang, Zhou and Zhou, 2007).

Through this research we are going to try to answer the following question: What are the factors that allow the reinforcement of the global independence of the Tunisian auditors in post revolution context?

In Tunisia, independence is regulated by Articles 262 and seq. of the Code of Commercial Companies (C.S.C) and by Act No. 2005-96 of 18 October 2005 on the strengthening of the security of financial relations (LRRSRF). Our motivation to this problematic is justified by the exploration of the context over revolution characterized by many mutations of economic environment.

\section{Literature Review and Research Hypotheses}

Real and perceived independence depends on factors related to the auditor on one side and factors related to the audited company of another.

Thus factors strengthening the independence of the auditor focus on his competence, professional qualifications and reputation of auditing firm (Ben Saad and Lesage, 2007).

Moreover, the competence of the auditors, which manifests in his capacity to apply knowledge, experience (Carolita and Rahardjo, 2012) and respect for the code of ethics (Asmara, 2016), favors the realization of a high quality of audit. Similarly, Suyono, (2012) states that experience is a skill acquired over a long period (Augustine and al., 2014) allows auditors to clarify revealed inaccuracies. In this context, Senjaya and Firnanti (2017) show that a more experienced auditor is able to detect, understand and analyze the cause of the inexactitudes found, which will lead to an improvement in the quality of the audit. In fact, Bertin (2002) attests that experienced auditors are able to detect and report more fraud and mistakes than less experienced ones and the experience positively influences the quality of the real independence of the external auditors (Lawensohn and al., 2005). 
In addition, the experience will preserve an intellectual independence with regard to the audited company (Prat-Dit-Hauret, 2003) and reinforce the perceived independence of the auditor. For this, we make the following hypothesis:

H1. The experience reinforces the real and perceived independence of the auditor.

Moreover, the quality of formation is estimated from an academic training which aims to acquire communication skills and critical thinking among future auditors (Bertin, 2002) for the good conduct of their auditing mission.

In this sense, Sori and Karbhari (2017) emphasize the need to improve transparency of the mission and promote the application of best practices of good governance. This requires important auditor's formation, and the enhancement of the application of the auditor independence regulation.

In this context, TranVu (2009) argues that formation is a key component in determining the quality of detection of anomalies. Formation is not only a necessary means to maintain a better assessment of the accounts, but also a factor of strengthening the real independence of the external auditor (Rent, 2006). The training is considered as a component of the skill that allows to strengthen the independence of the auditor and his image on the audit market. For this, we make the following hypothesis:

H2. Formation reinforces the real and perceived independence of the auditor.

Besides, the sector specialization which is a strategy adopted by audit firms to develop expertise in a particular industry requires the firm to restructure human capital and technologies (Wang and al., 2011). This specialization is a necessary adjustment for the adaptation of the mission to the specificities of the sector of the client's business (Piot 2005).

In fact, companies with high cost of agency seek to appoint an auditor specialized in their industry to improve audit quality (O'Keefe and al. 1994).

In addition, financial statement users are responding positively to the choice of a specialized auditor's firm (Harris, Tate and Zimmerman, 2017) resulting in lower capital cost and positive abnormal returns (Robin and Zhang, 2015). In this sense, Kharuddin and Basioudis (2017) add that the benefits of economies of scale achieved as a result of specialization in the industry, passed on by the auditor to his client, are significant (Fung, Gul, and Krishnan, 2012). Furthermore, Wang and al. (2011) show that the sector specialization is regarded by the public as a means of ensuring quality of auditing. For this reason, companies which employ a specialist firm are willing to pay a bonus of specialty to their auditor as they are expecting to get a good quality of audit and a high level of independence (Audousset-Coulier, 2009). So, we make the following hypothesis:

H3. The sector specialization reinforces the real and perceived independence of the auditor.

About the reputation of the auditing firm, Watts and Zimmerman (1986) show that the audit market is based on the reputation of the external auditors resulting from previous missions. 


\section{Ml Macrothink}

International Journal of Accounting and Financial Reporting

ISSN 2162-3082

2019, Vol. 9, No. 1

Thus, reputation is a key element for business continuity of the audit firms (Jacquillat and Pastré, 2011). So an auditing firm of good reputation seems to offer more independence to its auditors for fear of losing this competitive advantage. Anderson and Zeghal (1994) certify that these firms seek to maintain real independence of their external auditors by demanding compliance with the rules of professional standards.

For this, the public relies on the reputation of the auditing firm as a guarantee of auditing quality since the good reputation is a way that enables an audit firm to attract auditors of high qualification.

TranVu (2009) considers that the "Big Four" and auditing firms belonging to an international network of auditing firms are of good reputation, since the public perception says that auditors belonging to firms with good reputation probably have a high resilience against the pressures. In this sense, Wilson (2015) adds that audit quality is influenced by two mechanisms: litigation incentives and reputation incentives (Skinner and Srinivasan, 2012).

In addition, reputable auditing firms have low financial dependence on their customers which ensures the independence of their auditors (Rent, 2006). For this reason, auditing firm's reputation is presented as an enhancing factor for the real and perceived independence of the auditor (Prat-Dit-Hauret, 2003; Rent, 2006; Daniels and Booker, 2011). Hence the following hypothesis:

H4. The reputation of the audit firm reinforces the real and perceived independence of the auditor.

On another side, the factors of strengthening the independence of the auditor which are dependent on the audited company are focused on the governance structures. These factors are the Audit Committee, the legal audit mandate and the voluntary rotation of external auditors.

The audit committee is an internal team composed of directors appointed by the general assembly that helps in corporate governance monitoring by undertaking assessments and issuing recommendations. Janin and Piot (2010) state that the audit committee must monitor the quality and the reliability of financial statements, minimize income management, to ensure on relations within the organization and try to establish an interface between the independence of the auditor and members of senior management (Imhoff, 2003).

Zhang, Zhou and Zhou (2007) argue that the committee should be vigilant regarding the real independence of the auditor and the conditions for the exercise of his mission. For this reason, Lindberg and Beck (2002), and Ahmad Abu Bakar (2009) prove that the existence of a committee reinforces the real independence of the auditor (Mills and al., 2011).

Moreover, Lisic, Myers, Seidel, and Zhou (2017) add that committees have significant accounting expertise and are more likely to challenge management's financial reporting decisions (Pomeroy, 2010) which promotes the independence of the auditor. For this reason, we conclude that the audit committee reinforces independence of the auditor (Prat-Dit-Hauret, 2003; Godowski and Bertin, 2010). Hence the following hypothesis: 


\section{$\triangle$ Macrothink}

International Journal of Accounting and Financial Reporting

ISSN 2162-3082

2019, Vol. 9, No. 1

H5. The presence of Audit Committee reinforces the real and perceived independence of the auditor.

Moreover, the legal duration of the audit mandate, which is set to a maximum period of nine years (Omri and al., 2009), reduces the possibilities of changing the auditor which significantly minimizes managerial pressures that derive from the renewal of his audit mandate (Pigé, 2000). This legal duration reinforces the auditor's ability to resist the pressures because throughout this period the auditor is assured of his future fees, hence he will be able to report the anomalies (Piot and Schatt, 2010).

In addition, Senjaya and Firnanti (2017) add that a long audit period helps auditors better understand the mission, which facilitates the process of inspecting, detecting and reporting inaccuracies in the audit report.

Similarly, Geiger and Raghumandan (2002) found that the probability of reporting an audit opinion with reserve increases with the age of the audit mandate. On the other hand, the stakeholders believe that a long term of office improves audit quality and the independence of the auditors (Chi and Huang, 2005). So, we make the following hypothesis:

H6. The legal duration of the audit mandate reinforces the real and perceived independence of the auditor.

As for the voluntary rotation of auditors, the regulations have after the Enron case limited the number of years of the mandate of the external auditor (Gul and al., 2007). In Tunisia, the company is obliged to change the auditor after the accumulation of three mandates for an individual and five mandates for a corporation. Firth and al. (2012) argue that the rotation increases competition among auditing firms which strengthens the independence of its auditors to result in a differentiation in the quality of their services and limit the familiarity between the audit team and audited firm.

So, Piot and Janin (2010) argue that the established relationship of familiarity is likely to compromise the perceived independence of the auditor and increase the risk of irregularities (Kamath and al., 2017).

Several researchers show that financial market participants perceive that a very long term between the auditor and his client is a threat to his independence. Thus, stakeholders believe that rotation is the best solution to strengthen the independence, since it reinforces the professional skepticism of the auditor. For this Daniels and Booker (2011) found that the imposition of a limited number of years of an audit can reassure shareholders as to the objectivity and integrity of auditors allows them to maintain the confidence of stakeholders. In addition, this rotation affects the perceived independence of the audit (Ayorinde and al., 2016). For this, we make the following hypothesis:

H7. The voluntary rotation reinforces the real and perceived independence of the auditor. 


\section{Mll Macrothink}

\section{Research Methodology}

To test our research hypotheses, we, on the one hand, present our samples, data collection method, the presentation of two research models that test the real and perceived independence to end them with the measuring instruments of variables.

\subsection{Samples and Data Collection}

To test the real independence, the population of our study is composed of charted accountants registered in the Order of Chartered Accountants of Tunisia in 2017. The sample size consists of 811 chartered accountants who belong to auditing firms of different sizes. In addition, to test the perceived independence, the studied population is composed of members of the general assemblies in companies of different sizes and from different industries and they operate in the Tunisian financial market.

Since the quality of independence of the audit is a specific theme, we based our study on questionnaire which the most used method of collecting data by the literature (Windsor and Ashkanasy, 1995).

\subsection{Models of Research}

To determine the factors that enhance the real and perceived independence of the auditor, we propose two models to be tested using two simple linear regressions.

$$
\begin{aligned}
\mathrm{RI}_{i} & =\alpha_{0}+\alpha_{1} \text { EXP }_{i}+\alpha_{2} \text { FOR }_{i}+\alpha_{3} S S_{i}+\alpha_{4} \text { REP }_{i}+\alpha_{5} \text { COMITE }_{i} \\
& +\alpha_{6} \text { DOM }_{i}+\alpha_{7} \text { ROT }_{i}+e_{i}
\end{aligned}
$$

and,

$$
\begin{aligned}
\mathrm{PI}_{i} & =\alpha_{0}+\alpha_{1} \text { EXP }_{i}+\alpha_{2} \text { FOR }_{i}+\alpha_{3} S S_{i}+\alpha_{4} \text { REP }_{i}+\alpha_{5} \text { COMITE }_{i} \\
& +\alpha_{6} \text { DOM }_{i}+\alpha_{7} \text { ROT }_{i}+e_{i}
\end{aligned}
$$

Avec:

- $\quad$ RI: The real independence of the external auditor $\mathrm{i}$

- PI: The perceived independence by the member of the general assembly $\mathrm{i}$

- $\quad$ EXP: Experience of the external auditor $\mathrm{i}$

- FOR: Formation of the external auditor $\mathrm{i}$

- SS: Sector specialization of the auditing firm containing the external auditor $\mathrm{i}$

- $\quad$ REP: Reputation of the auditing firm containing the external auditor $i$

- COMITEE: Presence of auditing committee in the audited enterprise by the external auditor i

- DOM: the legal duration of the mandate of the audit of the external auditor $i$

- ROT: the voluntary rotation of the external auditor $\mathrm{i}$ 
- $\alpha$ : parameter to be estimated

- e: error term

\subsection{Presentation of Variables and Measuring Instruments}

The variables measuring instruments are adopted by reference to the literature taking into account the specificities of our Tunisian context.

\subsubsection{Measurement of the Dependent Variable "Real Independence"}

The experimental method of scenarios allows the testing of the effect of independent variables on the dependent variable using subjects' decisions on hypothetical situations.

So, in order to measure the quality of independence of the external auditor, researchers use an experimental method based on scenarios of four versions by exposing situations to which the auditor must make a judgment on a Linkert scale of 1 to 7 (Sweeney and Roberts, 1997; Prat-Dit-Hauret, 2003). The real independence is calculated on a cumulative score from the four scenarios. Prat-Dit-Hauret (2003) show that the cumulative score allows to determine the level of each participant as follows:

$\rightarrow 4 \leq$ cumulative score $\leq 11$ : weak real independence quality.

$\rightarrow 12 \leq$ cumulative score $\leq 20$ : an average real independence quality.

$\rightarrow$ Aggregate $>20$ : a high real independence quality.

Francis (2004) confirms the rationality of this classification since he considers that independence as a theoretical continuum can be classified. So, high quality of real independence means that the auditor can make an objective judgment that meets the professional standards of the profession.

\subsubsection{Measurement of the Dependent Variable "Perceived Independence"}

The measurement of this variable is made by calculating the audit fee (Audousset-Coulier, 2009). For this, we measure the perceived independence by fees paid as part of an audit. Loyer (2006) certifies that the compensation must be limited so that shareholders make sure it will not be a way that minimizes the independence of the external auditor. In this same logic, the Tunisian legislator has provided in Article 11 of Law No. 2002-16 of February the $4^{\text {th }}$ 2002, a schedule of fees payable to the auditor during the performance of an audit. The table below shows the scale of audit fees based on the gross balance sheet total.

Table 1. Schedule of payable fees of external auditors of Tunisian enterprises

\section{Level in thousand Tunisian dinars Highest auditing fees in Tunisian Dinar (gross balance sheet total)}

From 0 to 300 450 
From 300 to 1.000

1.150

From 1.000 to 3.000

2.150

From 3.000 to 7.000

3.150

From 7000 to 15.000

3.950

From 15.000 to 35.000

5.450

From 35.000 to 80.000

7.700

From 80.000 to 200.000

10.700

From 80.000 to 500.000

13.700

From 500.000 to 1000.000

17.450

\title{
3.3.3 Measurement of Independent Variables
}

We show in the table below measuring instruments of the independent variables which contain the empirical model.

Table 2. Measuring instruments of variables

Variables Symbo

The experience EXP

\section{Measuring instruments}

2 if the auditor has over 5 years of experience, 1 if the auditor has an experience between 2 and 5 years and 0 if the auditor has an experience of less than 2 years.

\section{Previous studies}

Betlin (2002)

(1)




\begin{tabular}{ll}
\hline of the auditing & international auditing network or a (1994); Daniels and \\
firm & "Big Four" and 0 if the auditor Booker (2011) \\
& belongs to a national auditing firm.
\end{tabular}
belongs to a national auditing firm.

\begin{tabular}{llll}
$\begin{array}{l}\text { The audit } \\
\text { committee }\end{array}$ & EOMIT & $\begin{array}{l}1 \text { if the auditor certifies the financial } \\
\text { statements of a company with an (1998) } \\
\text { audit committee and } 0 \text { otherwise. }\end{array}$ & and Davidson \\
\hline $\begin{array}{l}\text { Duration of DOM } \\
\text { Audit Mandate }\end{array}$ & $\begin{array}{l}\text { The number of consecutive years that Piot and } \\
\text { the auditor proceeded auditing of an (2010) } \\
\text { enterprise }\end{array}$
\end{tabular}

The voluntary ROT $\quad \begin{aligned} & 1 \text { if the auditor undergoes voluntary Kaplan and Mauldin } \\ & \text { rotation of } \\ & \text { external }\end{aligned}$
auditors

\section{Empirical Results}

We present below the results of the descriptive univariate, bivariate analysis, and the results of econometric models for each type of independence.

\subsection{Descriptive Analysis of the Dependent Variables}

After having handed our survey to 811 auditors registered in the Council of Accountants belonging to different regions of Tunisia, we have received only 70 responses, which is a response rate of $8.58 \%$. In addition, the questionnaire sent to the general assemblies of listed companies reveals response rate received equal to $15.38 \%$. This rate is acceptable compared to other similar studies in the same context (Abu Bakar Ahmad, 2009 with a 14.4\% response rate; Lindberg and Beck, 2002 with a $23 \%$ response rate).

The analysis of the real independence appears in Table 3 Panel A, while the perceived independence is presented in Table 3 panel $\mathrm{B}$.

Table 3. Descriptive statistics of dependent variables

\section{Panel A}

\section{The Real \\ Independence}

$$
\begin{aligned}
& \text { Number of First quartile Third quartile Average Variance } \begin{array}{l}
\text { Standard } \\
\text { observations }
\end{array} \\
& \text { deviation }
\end{aligned}
$$




$\begin{array}{llllll}70 & 21 & 27 & 24.116 & 14.479 & 3.805\end{array}$

\section{Panel B}

\section{The Perceived Independence}

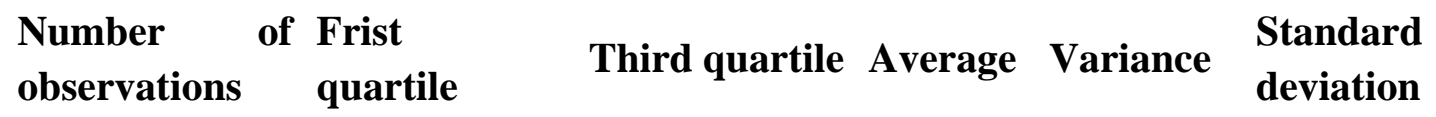

$\begin{array}{llllll}49 & 3150 & 17450 & 9363.265 & 26.116 & 15.743\end{array}$

In Table 3 panel A, we find that the average of independence of auditors is 24,116 while it is 14.2 for French sample of 152 auditors (Prat-Dit-Hauret, 2003). Panel B of the same table shows that $75 \%$ of the population of the shareholders pay audit fees around 17,450 .

We also note that the variance has a relatively high value in both Panels which shows the existence of heterogeneity of answers.

\subsection{Univariate Analysis of Dependent Variables}

Based on the analysis of four scenarios of audit, we note that the real independence is a similarly sensitive quality to the social as well as to the economic model. Sweeney and Roberts (1997) emphasize that the independence of the external auditor is an ethical concept more than an economic concept.

In the other hand, the perceived independence of the external auditor is measured by the level of audit fees.

Table 4. The percentage of responses agreement and of auditing fees

\section{Panel A}

\section{Real independence}

scenario $1 \quad$ scenario 2

scenario 3 scenario 4

The percentage of

$\begin{array}{lllll}\text { responses agreement } & 12.84 & 8.56 & 4.27 & 0\end{array}$

\section{Panel B}

\section{Perceived independence}

\section{Auditing fees in TND Frequencies Frequencies percentage}




\section{0}

2150

3150

5450

7700

10700

13700

17450
5

6

4

4

6

6

5

14
10

12

8

8

12

12

10

28

Table 4 Panel A shows the percentages of the four scenarios. The first scenario with a social pattern exposes the percentage of the highest agreement. Thus, the sensitivity of independence is stronger for the social model than economic model that is presented in the other three scenarios. So, the auditor agrees to reduce his level of independence for relational reasons rather than for economic reasons (Sweeney and Roberts, 1997).

By observing the distribution of responses presented in Table 4 Panel B, we note that the minimum amount of audit fees amounted to 1150 TND with greater frequency corresponding to an amount of audit fees 17450 TND. We also note that there are two amounts of audit fees that have not been chosen by the shareholders namely 450 TND and 3950 TND.

\subsection{The Bivariate Analysis}

To check the existence of a relationship between the real independence (Panel A) and the perceived independence (Panel B) with all the independent variables, we perform an analysis of variance and the results will be presented in the following table:

Table 5. The bivariate analysis

Panel A

\begin{tabular}{lllllll}
\hline & & Sum of & Average of & & & \\
Real independence & & squares & squares & F & Pr & Spearman \\
\hline Experience & Inter group & 5.272 & 5.272 & 0.375 & 0.446 & 0.039 \\
& intra group & 939.8 & 14.027 & & &
\end{tabular}




\begin{tabular}{|c|c|c|c|c|c|c|}
\hline \multirow[t]{2}{*}{ Formation } & Inter group & 88.56 & 88.56 & 6.524 & $0.013 * *$ & $0.317 *$ \\
\hline & intra group & 910.417 & 13.588 & & & \\
\hline \multirow[t]{2}{*}{ Sector specialization } & Inter group & 95.833 & 95.833 & 7.109 & $0.01 *$ & $0.264 * *$ \\
\hline & intra group & 903.239 & 13.481 & & & \\
\hline \multirow[t]{2}{*}{ Reputation of the firm } & Inter group & 3.382 & 3.382 & 0.228 & 0.635 & 0.031 \\
\hline & intra group & 965.690 & 14.861 & & & \\
\hline \multirow[t]{2}{*}{ Audit committee } & Inter group & 124.706 & 124.706 & 9.556 & $0.003 *$ & $0.358^{*}$ \\
\hline & intra group & 874.367 & 13.050 & & & \\
\hline \multirow[t]{3}{*}{ Legal duration } & Inter group & 115.987 & 115.987 & 4.334 & $0.017 * *$ & $0.280 * *$ \\
\hline & intra group & 883.086 & 13.380 & & & \\
\hline & & & & & $0.070 * *$ & \\
\hline \multirow[t]{2}{*}{ Voluntary rotation } & Inter group & 47.975 & 47.975 & 3.380 & $*$ & $-0.166 * *$ \\
\hline & intra groupe & 951.097 & 14.195 & & & \\
\hline
\end{tabular}

Panel B

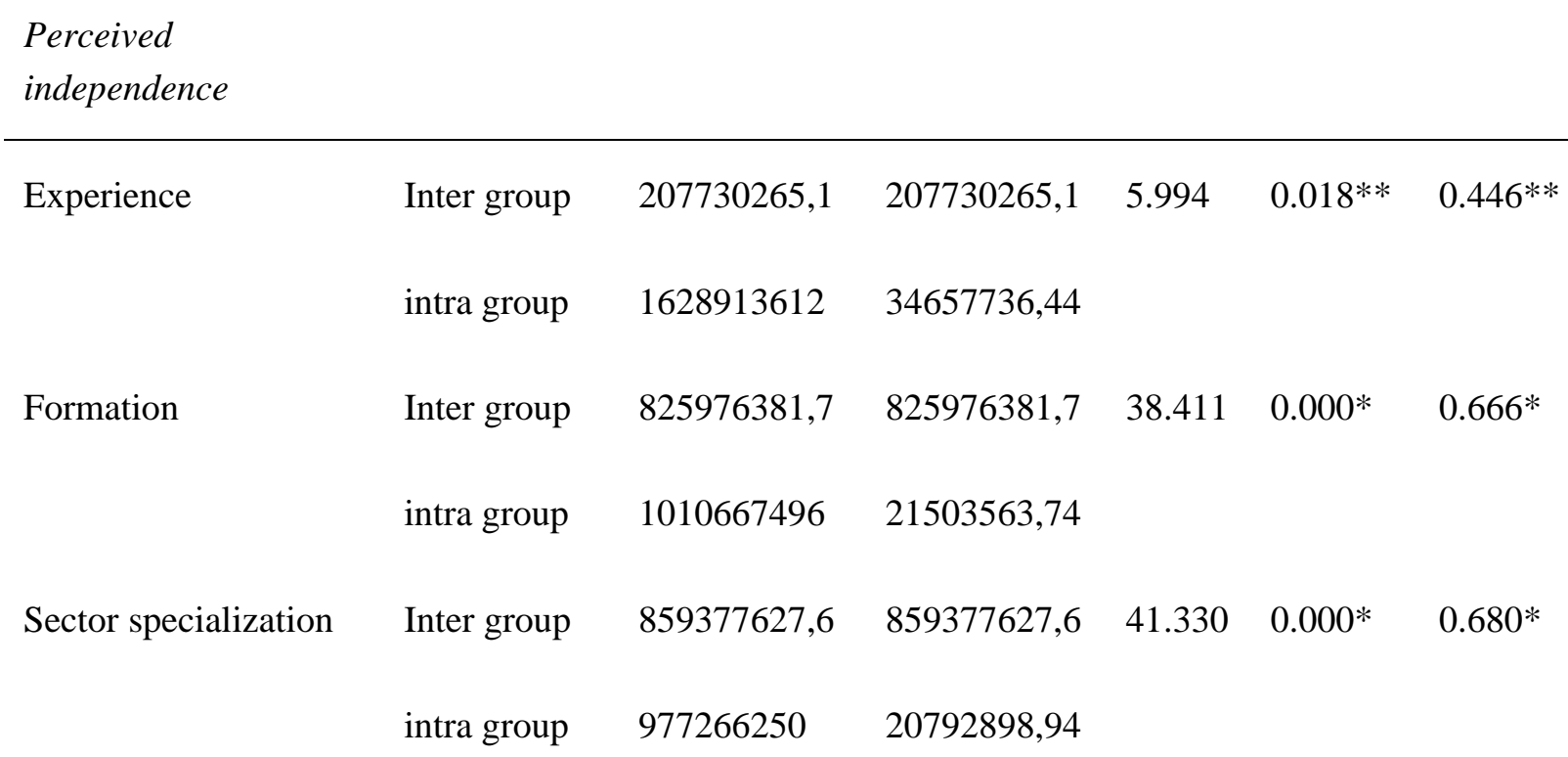




\begin{tabular}{|c|c|c|c|c|c|c|}
\hline \multirow[t]{2}{*}{ Reputation of the firm } & Inter group & 873463293,9 & 873463293,9 & 42.622 & $0.000 *$ & $0.668 *$ \\
\hline & intra group & 963180583,6 & 20493203,91 & & & \\
\hline \multirow[t]{2}{*}{ Audit committee } & Inter group & 839730441,2 & 839730441,2 & 39.590 & $0.000 *$ & $0.680 *$ \\
\hline & intra group & 996913436,4 & 21210924,18 & & & \\
\hline \multirow[t]{2}{*}{ Legal duration } & Inter group & 442422858,8 & 442422858,8 & 14.914 & $0.000 *$ & $0.418^{*}$ \\
\hline & intra group & 1394221019 & 29664276,99 & & & \\
\hline \multirow[t]{2}{*}{ Voluntary rotation } & Inter group & 563545792 & 563545792 & 20.805 & $0.000 *$ & $0.603 *$ \\
\hline & intra group & 1836643878 & 27087193,31 & & & \\
\hline
\end{tabular}

*significance at $1 \% * *$ significance at $5 \% * * *$ significance at $10 \%$

Table 5 Panel A shows that the firm's experience and reputation variables are not significant, this is confirmed by the Spearman correlation test. The results indicate the formation, the Sector specialization, Audit Committee and legal duration have a positively significant correlation with the real independence of the auditor (Sori and Karbhari, 2017; Mills and al. 2011; Geiger and Raghumandan, 2002). Only the variable "voluntary rotation" is significantly and negatively proving that it does not strengthen the real independence. Table 5 Panel B shows that experience, formation, sector specialization, the firm's reputation, the audit committee, the legal duration and the voluntary rotation are positively correlated with independence reinforce the perceived independence (Prat-Dit-Hauret, 2003).

\subsection{Multivariate Analysis and Discussion}

We establish a model by constructing associative combinations between the variables in order to achieve a better explanation of the dependent variable. For this, we use ANCOVA model which stands for the analysis of covariance (Evrard and al., 2003, Thornton and al., 2003). The results of ANCOVA are shown in the following table:

Table 6. Result of the covariance analysis model

\section{Panel A}

Real Independence

\begin{tabular}{llll}
\hline Variable & Standard error & Value & $\operatorname{Pr}>|\mathbf{t}|$ \\
\hline Constancy & 1.956 & 23.656 & $0.000^{*}$
\end{tabular}


Experience

Formation

Sector specialization

Reputation of the firm

Audit committee

Legal duration of the mandate

Voluntary rotation
0.965

0.938

1.042

1.839

0.939

0.184

0.989
0.648

0.504

1.611

$0.091 * * *$

1.879

$0.076^{* * *}$

1.401

0.449

1.579

$0.098 * * *$

0.377

$0.044 * *$

$-1.549$

$0.099 * * *$

\section{Panel B}

\section{Perceived Independence}

\begin{tabular}{llrl}
\hline Variable & Standard error & Value & Pr $>|\mathbf{t}|$ \\
\hline Constancy & 16532.018 & 1783.480 & $0.000^{*}$ \\
Experience & 2337.064 & 1.963 & $0.063^{* * *}$ \\
Formation & 2496.059 & 1.952 & $0.058^{* * *}$ \\
Sector specialization & 2360.871 & 1.968 & $0.062^{* * *}$ \\
Reputation of the firm & 2661.618 & 1.886 & $0.066^{* * *}$ \\
Audit committee & 3811.690 & 2.893 & $0.006^{*}$ \\
Legal duration of mandate & 2237.790 & -2.095 & $0.089^{* * *}$ \\
Voluntary rotat & 3811.690 & 1.544 & $0.033^{* * *}$
\end{tabular}

*significance at the level of $1 \%, * *$ significance at the level of $5 \%, * * *$ significance at the level of $10 \%$

Table 6 Panel A shows the results of ANCOVA for real independence.

Indeed, the variables experience and firm's reputation are not significant. In this sense, the seniority does not increase the real independence. So the main objective of the auditor, since the beginning of his career, is strict applying professional rules. However with seniority, the 
main objective will be maximizing his fees which may compromise his independence (Dirsmith and Covaleski, 1985).

Regarding the firm's reputation, the results show that belonging to an international auditing network does not strengthen the real independence of the auditors. This result contradicts the majority of the literature which shows the positive relationship between the independence and reputation of the auditing firm (Watts and Zimmerman, 1986; Jacquillat and Pastre, 2011). The table show that the formation, the sector specialization, the audit committee, the Legal duration of the mandate and the voluntary rotation are significantly positive and reinforces the real independence of the auditor (Wang and al. 2011; Bertin and Godowski, 2010; Piot and Schatt, 2010; Daniels and Booker, 2011). So a high degree of education strengthens the competence and by consequent the real independence of the auditor (Bertin, 2002).

In turn, the specialization of an audit firm in a specific industry ensures the auditor's ability to be rigorous and independent during the audit engagement (Schauer, 2002, Wang and al. 2011). Likewise, the real independence of the external auditors is improving with the presence of an audit committee. This committee who enjoys legitimate and informational power limits any pressure on the independence (Kalbers and Fogarty, 1993; Godowski and Bertin, 2010). Consequently the audit report will be an instrument of control and guarantees the reliability of the financial information.

In addition, the legal duration of the audit mandate enhances the real independence of auditors by allowing them to resist pressure because throughout this period the auditor is assured of his future fees (Piot and Schatt, 2010) and the possibilities of change (Pigé 2000).

However, voluntary rotation is significantly negative. So we can conclude that the voluntary rotation decrease the real independence of the external auditors. The independence of mandated auditors in companies that replace their auditor before the end of the legal period is less than the quality of independence of mandated auditors in companies that replace their auditors at the end of the period.

This result is explained by the fact that the voluntary rotation affects the auditor's perception of his future fees, which may be a threat to his diligence and his independence from the client.

Panel B which presents the results of ANCOVA for the perceived independence reveals that the covariance analysis of the experience variables, formation, sector specialization, the firm's reputation, the audit committee and the voluntary rotation are positively significant.

Thus, shareholders perceive that the auditors with over 5 years of experience are more independent, that the number of diplomas allows to the auditor to strengthen his competence and therefore his independence (Bertin, 2002), that the specialization of audit firms in a particular sector strengthens the independence of auditors (Piot, 2005; Wang and al., 2011), and they also perceive that the auditors belonging to an international network or to "Big Four" are more independent than the auditors working in national audit firms (Daniels and Booker (2011). Similarly, the Tunisian shareholders consider that the existence of an audit 
committee minimizes managerial pressures on the external auditor which reinforces his independence (Bertin and Godowski, 2010).

However, the variable legal duration of the audit mandate is significantly negative. This result means that investors perceive the long duration of the audit mandate a factor which weakens the perceived independence of the auditor. Indeed, managerial pressures force the auditor to give a favorable opinion on the financial statements (Chi Hang, 2005).

From all the above, we can conclude that the hypotheses H1, H4, H6 and $\mathrm{H} 7$ are rejected. Indeed, the experience, reputation of the audit firm and voluntary rotation reinforce the perceived independence and has no impact on the real independence (H1, H4 and H7).

In turn, the legal mandate strengthens the real independence and not also the perceived independence (H6). However, hypotheses H2, H3 and H5 are confirmed. In this sense, formation, sector specialization and the presence of an audit committee reinforce the real and perceived independence and thus they enhance the global independence of the auditor.

\section{Conclusion}

To success the certification of the accounts, the auditor must maintain his integrity and objectivity against pressures from managers of the audited company (Krishnamurthy and al., 2006). These pressures can be in the form of economic incentives which consist on increase of the audit mandate or the audit fees or as social incentives resulting from a familiarity or as personal relations with the audited firm (Defond and Zhang, 2014). The auditor is often exposed to these types of pressures that negatively affect the level of independence.

The interest of this paper is to identify factors that strengthen the global independence of the external auditor by analyzing the factors that enhance the real and perceived independence.

We conclude that formation, sector specialization and the audit committee reinforce the real and perceived independence. In fact, the auditor with a degree in higher education is enables to issue an unbiased audit report (Rent, 2006; TranVu, 2009), the sector specialization guarantees the auditor's ability to be rigorous and independent during the audit assignment (Audousset-Coulier, 2009), and the audit committee which has a legitimate and informative power limits any pressure on his independence (Godowski and Bertin, 2010).

The global independence of the auditor is a quality that requires the combination of different factors to protect it. This protection depends on the accumulation of the auditor's efforts and those of the audited company (Mills and al., 2011). So, the regulations are not the only way to reassure an expected level of independence.

In Tunisia, we conclude that achieving a global independence of the auditor is a difficult task because the factors studied reinforces mainly the perceived independence. The observation of real independence remains relatively difficult since it is an intangible quality. Hence, the observation of this quality and its degree of affection by the pressures exercised by manager still ambiguous (Chan and al. 2017). 
This paper presents like any other scientific contribution limits which are related to the data collection method. Indeed, the survey usually allows a limited number of observations and a problem of biased responses.

\section{References}

Abu Bakar, N. B., \& Ahmad, M. (2009). Auditor Independence: Malaysian Accountants' Perceptions. International Journal of Business and Management, 4(12), 129-141.

Anderson, T., \& Zeghal, D. (1994). The pricing of audit services: further evidence from the Canadian market. Accounting and Business Research, 24(95), 195-107.

Asmara, R. Y. (2016). Effect of competence and motivation of auditors of the quality of audit: Survey on the external auditor registered public accounting firm in Indonesia. European Journal of Accounting, Auditing and Finance Research, 4(1), 43-76.

Audousset-Coulier, S. (2009). L'utilisation des honoraires d'audit pour mesurer la qualité de l'audit : théorie et évidence. La place de la dimension européenne dans la Comptabilité Contrôle Audit. Strasbourg, France.

Augustine, O. O. (2014). Auditor tenure, Auditor independence and accrula based earnings management of quoted companies in Nigeria. European Journal of Accounting Auditing and Finance Research, 2(2), 63-90.

Ayorinde, B., \& Babajide, O. (2016). Audit Tenure, Rotation and Accounting Conservatism: Empirical Evidences from Nigeria. International Journal of Business and Economics Research, 4(6), 328-336.

Bamber, M. E., \& Iyer, V. M. (2007). Auditors' Identification with Their Clients and Its Effect on Auditors' Objectivity. Auditing: A Journal of Practice and Theory, 26(2), 1-24.

Ben Saad, E., \& Lesage, C. (2007). Des facteurs d'indépendance à un système d'indépendance: proposition d'une nouvelle grille d'analyse de l'indépendance de l'auditeur. Communication présentée au 28ème Congrès de l'AFC. Poitier.

Bertin, E. (2002). La formation à l'audit: déterminants, contenu et voies de recherche. L'Association Française de Comptabilité. Technologie et management de l'information: enjeux et impacts dans la comptabilité.

Bertin, E., \& Godowski, C. (2010). Interactions entre les acteurs du processus global d'audit et gouvernance de l'entreprise : une étude exploratoire. Crises et nouvelles problématiques de la Valeur, Nice, France.

Bigus, J. (2011). Auditors' liability with overcompensation and reputation losses, Quantitative Approaches in Management. Quantitative Approaches in Management, 33(2), 287-307.

Carolita, M. K., \& Rahardjo, S. N. (2012). Effect of work experience, independence, objectivity, integrity, competence and organizational commitment on the quality of audit results. Diponegoro Journal of Accounting, 1(2), 1-11. 


\section{$\triangle 1$ Macrothink}

International Journal of Accounting and Financial Reporting ISSN 2162-3082

Chan, L., Raman, K. K., Sun, L. L., \& Wu, D. (2017). The effect of ambiguity in an auditing standard on auditor independence: Evidence from nonaudit fees and SOX 404 opinions. Journal of Contemporary Accounting \& Economics, 13(1), 37-51.

Compernolle, T. (2008). De l'indépendance individuelle à l'indépendance collective de l'audit: l'apport de la théorie systémique. 29ème congrès de l'Association Francophone de Comptabilité.

Daniels, B. W., \& Booker, Q. (2011). The effects of audit firm rotation on perceived auditor independence and audit quality. Research in Accounting Regulation, (23), 78-82.

DeAngelo, L. E. (1981). Auditor independence, low balling and disclosure regulation. Journal of Accounting and Economics, 3(3), 113-127.

Defond, M., \& Zhang, J. Y. (2014). A review of archival auditing research. Journal of Accounting and Economics, 58(2-3), 275-326.

Dopuch, N., King, R. R., \& Schwartz, R. (2003). Independence in appearance and in fact: An experimental investigation. Contemporary Accounting Research, 20(1), 79-114.

Firth, M., Rui, M. O., \& Wu, X. (2012). How Do Various Forms of Auditor Rotation Affect Audit Quality? Evidence from China. International Journal of Accounting, 47, 109-138.

Fischer, M., Johnson, L., \& Elder, R. (2004). The Demand for Auditor Specialization and Its Effect on Private College and University Audit Fees. Research in Governmental and Nonprofit Accounting, (11), 117-133.

Fogarty, T. J., \& Dirsmith, M. W. (2001). Organizational socialization as instrument and symbol: an extended institutional theory perspective. Human Resource Development Quarterly, 12(3), 247-266.

Francis, J. R. (2004). What do we know about audit quality?. The British Accounting Review, $36(4), 345-368$.

Fung, S. Y. F., Gul, F. A., \& Krishnan, J. (2012). City-Level Auditor Industry Specialization, Economies of Scale, and Audit Pricing. American Accounting Association, 87(4).

Geiger, M., \& Raghunandan, K. (2002). Auditor tenure and audit reporting failures. Auditing: A Journal of Practice and Theory, 21(1), 67-78.

Gul, F. A., Jaggi, B., \& Krishnan, G. V. (2007). Auditor independence: Evidence on the joint effects of auditor tenure and non-audit fees. Auditing: A Journal of Practice and Theory, $26(2), 117-142$.

Harris, E., Tate, S., \& Zimmerman, A. (2017). Does Hiring a Local Industry Specialist Auditor Matter for Nonprofit. Organizations?. Nonprofit and Voluntary Sector Quarterly.

Imhoff, A. E. (2003). Accounting quality, audit, and corporate governance. Accounting Horizons, 117-128.

Ireland, J., \& Lennox, C. (2002). The Large Audit Firms Fee Premium: a Case of Selectivity 
Bias?. Journal of Accounting Auditing and Finance, 17, 173-91.

Jacquillat, B., \& Pastré, O. (2011). Les missions de l'audit et le livre vert de la commission européenne.

Janin, R., \& Piot, C. (2010). L'influence des auditeurs externes et des comités d'audit sur le contenu informatif des manipulations comptables. La Revue des Sciences de Gestion, 233, 23-33.

Kamath, R., Huang, T. C., \& Moroney, R. (2017). Auditor rotation and perceived audit quality: The effect of audit fees and industry specialization. OpenConf Peer Review and Conference Management System. AFAANZ Conference.

Kaplan, S. E., \& Mauldin, E. G. (2008). Auditor rotation and the appearance of independence: Evidence from non-professional investors Steven. Journal of Accounting and Public Policy, 27(2), 177-192.

Kharuddin, K. A. M., \& Basioudis, I. G. (2017). Big 4 audit fee premiums for national - and city - specific industry leadership in the UK: Additional evidence. International Journal of Auditing, 22(1), 65-82.

Knapp, M. C. (1985). Audit Conflict: An Empirical Study on the perceived Ability of Auditors to Resist Management Pressure. The Accounting Review, 60, 202-211.

krishnamurthy, S., Zhou, J., \& Zhou, N. (2006). Auditor Reputation, Auditor Independence, and the Stock-Market: Impact of Andersen's Indictment on Its Client Firms. Contemporary Accounting Research, 23(2), 465-490.

Lindberg, D. L., \& Beck, F. D. (2002). Before and After Enron: CPAs' Views on Auditor Independence. CPA Journal, 74(11), 36.

Lisic, L. L., Myers, L. A., Seidel, T. A., \& Zhou, J. (2017). Does Audit Committee Accounting Expertise Help to Promote Audit Quality? Evidence from Auditor Reporting of Internal Control Weaknesses. $\quad$ Retrieved from https://papers.ssrn.com/sol3/papers.cfm?abstract_id=2948134

Lowenshon, S., Johnson, E. L., \& dan Elder, J. R. (2005). Auditor Specialization and Perceived Audit Quality, Auditee Satisfaction, and Audit Fees in the Local Government Audit Market. Journal of Public Budgetting, Accounting and financial Management, 18(2), 139-166.

Loyer, P. (2006). L'indépendance de l'auditeur financier: une approche des facteurs déterminants. Thèse de doctorat en science comptable. Université de Lille 1.

Mangena, M., \& Pike, R. (2005). The effect of audit committee shareholding, financial expertise and size on interim financial disclosures. Accounting and Business Research, 35(4), 327-349.

Mills, P. W., Bruschett, W. R., Crowley, P., Hannaford, G. B., Kinney, J. E., Kriegler, A. J., $\&$ Weiss, P. R. (2011). Amélioration de la qualité de l'audit. un point de vue canadienne, 
indépendance, Conseil Canadien sur la Reddition des comptes.

Omri, A., Ghorbel, F. H., \& Baklouti, F. T. (2009). Impact de l'audit externe sur la qualité du résultat comptable: Cas des entreprises tunisiennes cotées. Revue Gouvernance Autonome, 6(2), 1-19.

Pigé, B. (2000). Qualité de l'audit et gouvernement d'entreprise: le rôle et les limites de la concurrence sur le marché de l'audit. Comptabilité Contrôle Audit, 2, 133-151.

Piot, C. (2005). Concentration et spécialisation sectorielle des cabinets d'audit sur le marché des sociétés cotées en 1997-1998. Comptabilité - Contrôle - Audit, 11(2), 149-173.

Piot, C., \& Schatt, A. (2010). Comment renforcer la réglementation sur l'indépendance des auditeurs? Quelques leçons tirées du marché français. Crises et nouvelles problématiques de la Valeur.

Prat-Dit-Hauret, C. (2003). L'indépendance perçue de l'auditeur. Revue Française de Gestion, 29(147), 105-117.

Quick, R., \& Warming-Rasmussen, B. (2015). An Experimental Analysis of the Effects of Non-audit Services on Auditor Independence in Appearance in the European Union: Evidence from Germany 2015. Journal of International Financial Management and Accounting, 26(2), 150-187.

Richard, C. (2003). L'indépendance de l'auditeur: Pairs et manques. Revue Française de Gestion, 27(147), 119-131.

Richard, C. (2006). Why auditor can't be competent and independant: A French case study. European Accounting Review, 15(2), 123-179.

Robin, A. J., \& Zhang, H. (2015). Do Industry-Specialist Auditors Influence Stock Price Crash Risk?. Auditing: A Journal of Practice and Theory, 34(3), 47-79.

Schauer, P. C. (2002). The effects of industry specialization on audit quality: an examination using bid-ask spreads. Journal of Accounting and Finance Research, 10(1), 76-86.

Senjaya, M., \& Firnanti, F. (2017). Auditor Characteristics, Audit Tenure, Audit Fee and Audit Quality. Global Journal of Business and Social Sciences Review, 5(3).

Skinner, D., \& Srinivasan, S. (2012). Audit Quality and Auditor Reputation: Evidence from Japan. Accounting Review, 87(5), 1737-1765.

Sori, M., \& Karbhari, Y. (2017). Auditor Reputation and Auditor Independence in an Emerging Markets. Contemporary Accounting Research, 23(2), 465-490.

Suyono, E. (2012). Determinant Factors Affecting Audit Quality: An Indonesian Perspective. Global Review of Accounting and Finance, 3(2), 42-57.

Sweeney, J. T., \& Roberts, R. W. (1997). Cognitive moral development and auditor independence. Accounting, Organizations and Society, 22(3), 337-352. 


\section{MInstitute ${ }^{\text {Muk }}$}

International Journal of Accounting and Financial Reporting

ISSN 2162-3082

Tan, H., \& Libby, R. (1997). Tacit Managerial Versus Technical Knowledge as Determinants of Audit Expertise in the Field. Journal of Accounting Research, 35, 97-113.

Thornton, J., Reinstein, I., \& Miller, L. (2003). User primacy, positive accounting theory, and non-audit services: evidence from the SEC's Independence Hearings. Accounting and the Public Interest, 3, 36-57.

Tran Vu, T. V. (2009). Les dimensions de la performance des cabinets d'audit légal. Comptabilité, Contrôle et Audit, 18, 200.

Wang, B., \& Xin, Q. (2011). Auditor choice and accruals patterns of cross-listed firms. Journal of Accounting Research, 4(4), 233-251.

Watts, R. L., \& Zimmerman, J. L. (1986). Positive Accounting Theory. Englewood Cliffs.

Wilson, R. (2015). The Impact of Auditor Reputation on Jurors' Assessment of Auditor Liability in a Limited Liability Regime: Financially Important Nonpublic Clients. Journal of Accounting and Finance, 15(1), 23-39.

Windsor, C. E., \& Ashkanasy, R. D. (1995). The Effects of Engagement Factors on Auditor Independence: Canadian Evidence. Journal of International Accounting, Auditing and Taxation, 7, 163-179.

Zhang, Y., Zhou, J., \& Zhou, N. (2007). Audit committee quality, auditor independence, and internal control weaknesses. Journal of Accounting and Public Policy, 26(3), 300-327.

\section{Appendix: Real Independence}

Scenario 1

A financial manager has taken a certain amount of company assets without authorization of the General Directorate to pay hospital expenses of his father. After a time, he repaid that amount which is deemed significant. The external auditor decides not to mention this in his audit report.

Scenario 2

A financial manager of a company decides to stop the research and development costs related to a new product. However, the set amount, which is deemed significant, is probably greater than the amount to be recovered on the future economic benefits.

Scenario 3

A financial manager has taken some supplier invoices, as these debts are not recorded in accounting. The amount of the debt exceeds the materiality level set by the hypothetical auditor. However, he did not report this anomaly in his audit report. 


\section{Macrothink \\ International Journal of Accounting and Financial Reporting \\ ISSN 2162-3082 \\ 2019, Vol. 9, No. 1}

Scenario 4

In a company, the external auditor has found that there is no registration of certain purchase invoices in accounts in which the amount of these invoices exceeded the significance issued by himself. However, he decided not to report this error.

\section{Copyright Disclaimer}

Copyright for this article is retained by the author(s), with first publication rights granted to the journal.

This is an open-access article distributed under the terms and conditions of the Creative Commons Attribution license (http://creativecommons.org/licenses/by/4.0/) 